\title{
Fotoindukált folyamatok homogén és heterogén rendszerekben: spektroszkópia, fotolízis és fotokatalízis
}

\author{
VALICSEK Zsolt, SZABÓNÉ BÁRDOS Erzsébet, FODOR Lajos és HORVÁTH Ottó* \\ Pannon Egyetem, Mérnöki Kar, Természettudományi Központ, Környezeti és Szervetlen Fotokémia Kutatócsoport, \\ Egyetem u. 10., 8200 Veszprém, Magyarország
}

\section{Bevezetés}

A Pannon Egyetem (korábban Veszprémi Vegyipari, majd Veszprémi Egyetem) Általános és Szervetlen Kémia Tanszékén jó 40 évvel ezelőtt kezdődtek meg a fotokémiai kutatások, melyek ma már az új szervezeti egység, a Környezeti és Szervetlen Fotokémia Kutatócsoport keretein belül folynak. A kísérleteket kezdetben - a tanszék koordinációs kémiai tapasztalataira alapozva - különböző fémkomplexekkel végeztük, melyek eleinte kizárólag szervetlen, majd később nagyobb méretű, a biológiai rendszerekben is fontos szerepet játszó aromás és porfinvázas ligandumokat tartalmaztak. Ilyen vegyületekkel különböző fotokatalitikus rendszereket is sikerült kialakítani. Utóbbiakhoz kapcsolódva fotoaktív félvezetők alkalmazásán alapuló heterogén fotokatalitikus eljárásokat is fejlesztettünk, pl. víztisztításra és napenergia-hasznosításra. A következő áttekintésben az elmúlt évtizedben elért eredményeinkből azokat ismertetjük, melyek talán legalkalmasabbak a csoport által végzett fotokémiai kutatások bemutatására.

Közismert, hogy a fotoindukált reakciók esetében az elektromágneses sugárzások közül az ibolyántúli vagy látható fény tartományába esők energiájával gerjesztjük a megfelelő fotoaktív részecskét, melyet a kívánt kémiai átalakulás elősegítésére alkalmazunk. Fotolizis esetében közvetlenül a gerjesztett részecske - általában ion vagy molekula - szerkezete, oxidációs állapota változik meg úgy, hogy a kívánt végterméket kapjuk. A gerjesztés során az adott vegyület elektronállapota módosul, melynek eredményeképp jelentős elektronsürüség kerül alacsonyabb energiaszintủ pályáról (HOMO) magasabb energiaszintűre (LUMO). Így az előbbi üresedésével megnő a gerjesztett részecske oxidációs, míg utóbbi betöltésével a redukciós potenciálja. (Hasonló változás lép fel fotoaktív félvezetők gerjesztésekor; tiltott sávot meghaladó energia hatására a vegyértéksávból a negatívabb potenciálú vezetési sávba kerül egy elektron, míg előbbiben egy pozitív töltésű lyukat hagy maga után.) Amennyiben az elektronátmenet kötő pályáról nemkötő vagy lazító pályára történik, a vegyületben kötéshasadás következhet be. Fontos megjegyezni, hogy - különösen összetett szerves molekulák esetében, melyek több kromofór csoporttal is rendelkeznek - a végbemenő fotokémiai reakció típusa függ a gerjesztő fény hullámhosszától. Ilyen esetekben megfelelő energiájú besugárzással a kívánt termék nagy szelektivitású előállítása valósítható meg.

A tágabb értelemben vett fotokatalizis során a fotoaktív részecske csak energia vagy töltés közvetítésére szolgál, s e folyamatokat követően visszatér kiindulási (alap)állapotába. Az energiaátadás általában ütközéssel történik, s akkor alkalmazzák, ha a vegyület, melynek kémiai átalakulása a cél, közvetlenül nem gerjeszthető (nem nyel el) a reakcióhoz szükséges hullámhossz-tartományban. Ekkor egy jó fényelnyelő, ú.n. érzékenyítő molekulát sugároznak be, mely hosszú élettartamú gerjesztett állapottal rendelkezve találkozik a célmolekulával, s extra energiája jelentős részét annak átadja. Töltésközvetítés esetén a gerjesztett fotokatalizátor oxidál vagy redukál egy célvegyületet, majd regenerálódik egy elektrondonorral vagy akceptorral. Amennyiben a bruttó reakció szabadentalpiaváltozása negatív, a fény csak az aktiválási energiát biztosítja, ha pozitív, akkor a besugárzási energia jelentős része beépül a folyamat végtermékébe. (Ekkor fotoszintézisről beszélünk.) A szigorú értelemben vett fotokatalízis esetében az indító fotokémiai lépésben képződik az a részecske, mely aztán alap elektronállapotban számos termikus katalitikus ciklusban vesz részt. Ilyen pl. a sztratoszférában a freonok fotodisszociációjában képződő klórgyök, ami az ózon bomlását katalizálja. Az általunk kidolgozott, ill. alkalmazott fotokatalitikus rendszerek alapvetően a töltésközvetítö típusba tartoznak.

\section{Fém-porfirin komplexek fotoindukált tulajdonságai}

\subsection{Szerkezeti és spektroszkópiai sajátságok}

A porfirinek szubsztituált porfinszármazékok, melyek körbezáródó konjugált kettőskötés-rendszerben 4 pirrolt tartalmaznak. Ezek síknégyzetesen elhelyezkedő nitrogénjei által a porfirinek merev négyfogú ligandumként visel-

* Tel.: +3688624000 / 6049; e-mail: horvath.otto@mk.uni-pannon.hu 
kednek (1. ábra). A pirrolgyürűk és a konjugált kötésrendszer révén a porfirinek eröteljes fényelnyelést mutatnak a látható tartományban, a 350-500 nm-nél elhelyezkedö, az $\mathrm{S}_{0}-\mathrm{S}_{2}$ átmenetnek megfelelö B- vagy Soret-sávok esetében $10^{5} \mathrm{M}^{-1} \mathrm{~cm}^{-1}$ nagyságrendü moláris elnyelési együtthatóval, míg az 550-850 nm-nél található, $\mathrm{S}_{0}-\mathrm{S}_{1}$ átmenetnek megfelelő Q-sávoknál $10^{4} \mathrm{M}^{-1} \mathrm{~cm}^{-1}$-es értékekkel. Nem véletlen, hogy a fotoszintézisben kulcsszerepet játszó fényhasznosító klorofillek is porfinszármazékok (klorinok) magnézium(II)-komplexei. Mivel kísérleteinket vizes oldatokban végeztük, a vizsgált porfirinek anionos (szulfonátofenil) vagy kationos (metil-piridínium) szubsztituenseket tartalmaztak (1. ábra).

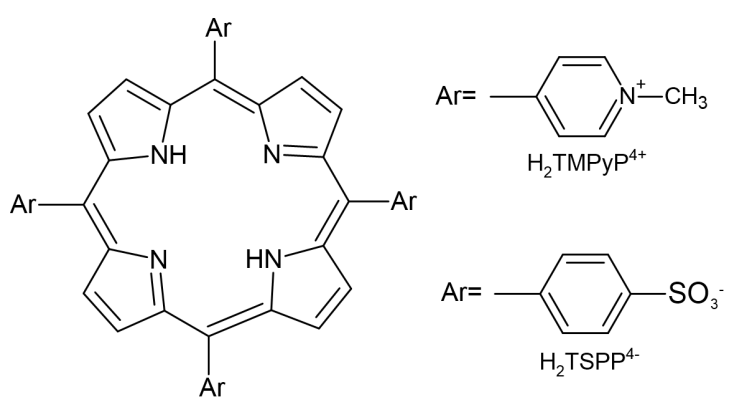

1. Ábra. Kationos és anionos porfirin szerkezetei képlete. $\mathrm{H}_{2} \mathrm{TSPP}^{4-}=$ 5,10,15,20-tetrakisz(4-szulfonátofenil)porfirin, $\mathrm{H}_{2} \mathrm{TMPyP}^{4+}=$ 5,10,15,20-tetrakisz(1-metil-4-piridínium)porfirin

A központi fémion méretétől, elektronkonfigurációjától (oxidációs állapotától) és síknégyzetes vagy tetraéderes koordinációra való hajlamától függően a fémporfirinek különböző szerkezettel, s ennek megfelelő elnyelési színképpel rendelkeznek ${ }^{1,2}$. Ennek alapján a fémporfirinek két legnagyobb csoportját a központi fémion mérete határozza meg. Amennyiben az ionsugár 85-90 pm-nél kisebb (pl. az $\mathrm{Al}^{3+}, \mathrm{Fe}^{3+}, \mathrm{Cu}^{2+}$ és $\mathrm{Pd}^{2+}$ ionok esetében), a fémion a koordinációs üreg belsejében, a ligandummal egy síkban helyezkedik el. Ha mérete meghaladja ezt az értéket (mint pl. a $\mathrm{Cd}^{2+}, \mathrm{Hg}^{2+}, \mathrm{Bi}^{3+}, \mathrm{Pb}^{2+}$ és $\mathrm{Ln}^{3+}$ vagyis lantanoida(III)ionoknál), akkor nem fér be teljesen az üregbe, s középpontja a ligandum síkján kívül esik ${ }^{3-6}$. Utóbbi esetben a komplexek csak egyensúlyi rendszerben léteznek, míg az előbbiben kinetikailag inertek, tehát fémion-felesleg nélkül sem disszociálnak. E szerkezeti eltérés jelentősen megszabja a két csoport spektrális sajátságait és fotokémiai viselkedését is. A központi fémion síkon kívüli helyzete a porfirin ligandum szerkezetének jelentősebb torzulását eredményezi, ami a Soretés Q-sávok esetében a szabadbázisú porfirin megfelelő elnyelési sávjához képest vöröseltolódásban nyilvánul meg, míg az $\mathrm{S}_{2}-\mathrm{S}_{0}$ emissziós sávokra vonatkozóan kékeltolódás jeletkezik (2. ábra ).

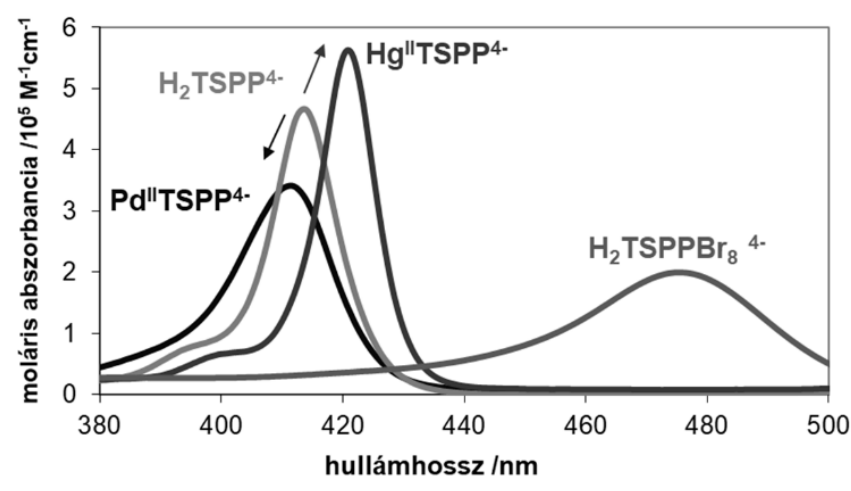

2. Ábra. Moláris elnyelési színképek a Soret-tartományban: anionos szabadbázisú porfirin $\left(\mathrm{H}_{2} \mathrm{TSPP}^{4-}\right)$; erősen torzított, oktabrómozott származéka $\left(\mathrm{H}_{2} \mathrm{TSPPBr}_{8}{ }^{4-}\right)$; egy tipikus normál ( $\left.\mathrm{Pd}^{\mathrm{II}} \mathrm{TSPP}^{4-}\right)$ és egy síkon kívüli ( $\left.\mathrm{Hg}^{\mathrm{II}} \mathrm{TSPP}^{4-}\right)$ fémporfirin

A normál fémporfirinek esetében a színképváltozást inkább a központi fémion atomi pályáinak és a ligandum HOMO orbitáljainak erőteljesebb átlapolása eredményezi utóbbiak energiájának jelentős csökkenését előidézve, míg a kölcsönhatás a LUMO pályákat nem érinti. Így a megfelelő Soret- és Q-sávok kékeltolódást mutatnak a ligadum elnyelési csúcsaihoz képest, míg az $\mathrm{S}_{2}-\mathrm{S}_{0}$ emissziós sávoknál vöröseltolódás figyelhető meg. Ugyanakkor az $\mathrm{S}_{1}-\mathrm{S}_{0}$ emissziós sávok mindkét típusú komplexnél kékeltolódást mutatnak, aminek a szabadbázisú és a fémporfirinek közti szimmetriaeltérés az oka. A szabadbázisú porfirinben a pirrol-nitrogének nem egyformák; két átlósan elhelyezkedőn $\mathrm{H}$ atom is van, míg a másik kettőn nincs, így a molekula csak $D_{2 h}$ szimmetriájú. Ennek spektroszkópiai következménye, hogy a Q-sávok (vagyis a megfelelő $\mathrm{S}_{1}$ állapotok) felhasadnak $\mathrm{Q}_{\mathrm{x}}$ és $\mathrm{Q}_{\mathrm{y}}$ sávokra (ill. $\mathrm{S}_{1 \mathrm{x}}$ és $\mathrm{S}_{1 \mathrm{y}}$ állapotokra). Egy fémion koordinációja során az aszimmetriát okozó hidrogének mint protonok távoznak, így mind a 4 nitrogén azonos helyzetü lesz, s a porfirin $\mathrm{D}_{4 \mathrm{~h}}$ ill. síkon kívüli szerkezetnél $\mathrm{C}_{4 \mathrm{v}}$ szimmetriájú a létrejövő komplexben, így az elöbb említett felhasadás megszünik. Mivel a szabadbázisú porfirinnél az $\mathrm{S}_{1}-\mathrm{S}_{0}$ emisszió az alacsonyabb energiájú $\mathrm{S}_{1 \mathrm{x}}$ állapotból megy végbe, a megfelelö $\mathrm{S}_{1 \mathrm{x}}-\mathrm{S}_{0}$ energiakülönbség kisebb a komplexek emissziós sávjainak megfelelő $\mathrm{S}_{1}-\mathrm{S}_{0}$ energiakülönbségnél.

Fontos megjegyezni, hogy a porfingyürün viszonylag zsúfoltan elhelyezkedő szubsztituensek jelentősen módosíthatják a síkszerkezetet, ami az elnyelési sávok vöröseltolódását okozza már a szabadbázisú porfirin esetében is. Ezt jól demonstrálja az oktabrómozott porfirin nyeregalakú torzulásából eredő drámai sáveltolódás (2. ábra), mely a megfelelő Cd(II)-komplex színképeiben még erőteljesebben jelentke$z_{i k}{ }^{7}$. Emellett az erős szerkezeti torzulás az emisszió élettartamát és hatékonyságát is mintegy harmadára csökkenti a sugárzás néküli energialeadás lehetőségeinek növelésével.

Síkon kívüli fémporfirinek esetében, ha a fémion-felesleg mellett növeljük a porfirin ligandum koncentráció- 
ját, bisz- vagy oligoporfirin-komplexek is képződhetnek egyensúlyi rendszerekben. Erre mutatnak jó példát anionos lantanoida(III)-biszporfirinek, melyek esetében két 1:1 (porfirin:fém) összetételü monomert egy fémion köt össze a negatív töltésű szulfonátofenil szubsztituensen keresztül kemény-kemény Lewis-féle sav-bázis kölcsönhatás révén (3. ábra $)^{8,9}$.

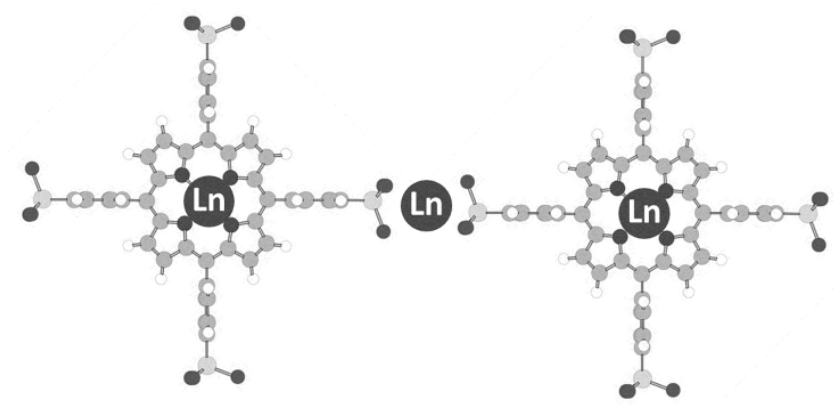

3. Ábra. Szulfonáto csoportokon át létrejött kapcsolat két monomer lantanoida(III)-porfirin közt egy biszporfirin komplexben

E biszporfirinek képződését nem kíséri az abszorpciós sávok olyan eltolódása, mely a sokkal erősebb „stacking” kölcsönhatásnál lép fel, amikor szendvics-jellegű szerkezetben a párhuzamos síkkal helyezkednek el a porfirinek viszonylag közel egymáshoz. Utóbbi esetben a megszünik a monomerekre jellemző emisszió, a lantanoida(III)-komplexeknél a gyenge kölcsönhatás miatt alig csökken a fluoreszcencia hatékonysága és élettartama ${ }^{8,9}$. Fontos megjegyezni, hogy a különböző méretű lantanoida(III)ionok alkalmazásával jól hangolható a központi fém síkon kívülisége, s ezáltal a komplex fotofizikai és -kémiai viselkedése ${ }^{9,10}$.

\subsection{Fotokémiai viselkedés}

A normál és síkon kívüli fémporfirinek eltérő szerkezete jelentősen különböző fotokémiai viselkedést is eredményez. Míg az utóbbi csoportba tartozó komplexek gerjesztése - akár Soret-, akár Q-sávos besugárzással - olyan, a ligandumról a központi fémionra irányuló töltésátmenethez (LMCT) vezet, melynek révén csökken a fémion oxidációs száma, s nő a mérete. Ez gyengíti a koordinációs kötést, $\mathrm{s}$ elösegíti, hogy a redukált fémion távozzon, míg az oxidált porfirin irreverzibilis gyürühasadást szenved, hacsak megfelelő elektrondonor nem áll rendelkezésre a regenerálásához ${ }^{8,9}$. Ilyen komplexek alkalmazása sokkal nehézkesebb fotokatalitikus célokra, hisz a fémionfelesleg mellett olyan regenerálószerek szükségesek, melyek oxidációja vagy redukciója a kívánt célterméket szolgáltatja. Ezzel szemben a normál fémporfirinek gerjesztése önmagában nem idéz elő LMCT reakciót. A kinetikailag inert szerkezet következtében a központi fémion csak akkor redukálódik (külsőszférás töltésátvitellel), ha a rendszerhez kellőképp hatékony elektrondonort adunk. Azonban egy ilyen redukció sem vezet a fémion kilépéséhez, hanem lehetőséget ad alkalmas elektronakceptor jelenlétében a fotoindukált lépésben szerzett elektron továbbadására termikus reakcióban vagy ugyancsak fotogerjesztés hatására.

\subsubsection{Reduktív fotokatalitikus rendszerek}

Normál (kinetikailag inert) fémporfirinek fotokatalitikus alkalmazására a fent vázolt rendszerben kationos kobalt(III)- és mangán(III)-porfirinek bizonyultak alkalmasnak $^{8,11,12}$. A pozitív töltésü ligandum növelte a központi fémion oxidáló hatását gerjesztett állapotban. Így az alkalmazott elektrondonorral, mely esetünkben trietanol-amin (TEOA) volt, oxigénmentes körülmények közt a központi fémion oxidációs száma eggyel csökkent, s a megfelelő Co(II)- ill. Mn(II)-porfirin képződőtt (4. ábra) (1).

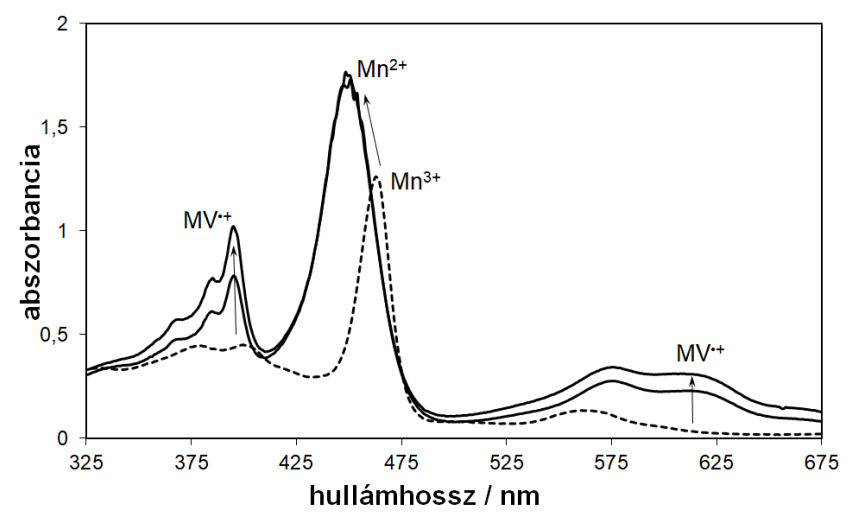

4. Ábra. Kationos $\mathrm{Mn}$ (III)-porfirint $\left(5 \times 10^{-6} \mathrm{M}\right)$, TEOA-t $\left(5 \times 10^{-4} \mathrm{M}\right)$ és $\mathrm{MV}^{2+}$-t tartalmazó rendszerben mért színképek 0 , 10 és 30 perc besugárzást követően ( $\lambda=465 \mathrm{~nm}$-es fénnyel, $1 \mathrm{~cm}$ vastag küvettában)

$\mathrm{M}(\mathrm{III}) \mathrm{TMPyP}^{5+}+\mathrm{TEOA}+\mathrm{h} v \rightarrow \mathrm{M}(\mathrm{II}) \mathrm{TMPyP}^{4+}+\mathrm{TEOA}_{\text {ox }}(1)$

A kisebb töltésű fémionok nagyobb méretűek, így komplexeik elnyelési sávjai kékeltolódást mutatnak a kiindulási vegyületekéihez képest. A vizsgált fotokatalitikus rendszerekben elektronakceptorként a színtelen metilviologén $\left(\mathrm{MV}^{2+}\right)$ szolgált, mely a redukált fémiontól vett át elektront kék színü $\mathrm{MV}^{++}$gyökkationt szolgáltatva (2). Ez a lépés ugyancsak fotogerjesztés hatására ment végbe.

$\mathrm{M}(\mathrm{II}) \mathrm{TMPyP}^{4+}+\mathrm{MV}^{2+}+\mathrm{h} v \rightarrow \mathrm{M}(\mathrm{III}) \mathrm{TMPyP}^{5+}+\mathrm{MV}^{\bullet+}$

A képződött $\mathrm{MV}^{\cdot+}$ segédkatalizátor jelenlétében képes a víz protonját redukálni hidrogént fejlesztve, így a rendszer a látható napsugárzás hasznosítására alkalmas.

A nikkel(II) kationos porfirinkomplexe az előzőektől eltérő mechanizmussal játszik szerepet hasonló fotokatalitikus rendszerben. Ebben az esetben besugárzás hatására nem változik a központi fémion oxidációs állapota, a $\mathrm{MV}^{++}$ gyökkation mégis jelentős mértékben felhalmozódik ${ }^{13}$. Ez arra utal, hogy az elektrondonor már alapállapotban kölcsönhatásba lép a komplexszel - asszociátumot képezve (3), mely gerjesztés hatására közvetlenül a TEOA elektronját adja át az elektronakceptornak $\left(\mathrm{MV}^{2+}\right)$ (4).

$$
\begin{array}{r}
\mathrm{Ni(II)TMPyP}{ }^{4+}+\text { TEOA } \leftrightarrows \mathrm{Ni}(\mathrm{II}) \mathrm{TMPyP}^{4+}-\mathrm{TEOA} \\
\left.\mathrm{Ni(II)TMPyP}{ }^{4+}-\mathrm{TEOA}+\mathrm{MV}^{2+}+\mathrm{h} v \rightarrow \mathrm{Ni}^{+\mathrm{II}}\right) \mathrm{TMPyP}^{4+}+ \\
+\mathrm{MV}^{++}+\mathrm{TEOA}_{\text {ox }}
\end{array}
$$


Az asszociátum képződése által okozott spektrális változás az elektrondonor ligandumhoz kötődésére utal. Ezt erősíti meg a szabad profirinnel kapott hasonló, de jóval kisebb hatékonyságú töltésátvitel. A mechanizmust villanófény fotolízis mérésekkel igazoltuk. Míg a Mn(III)- és Co(III)-porfirinek esetében a kiindulási komplex triplett gerjesztett állapotát a TEOA dinamikusan kioltotta - igazolva a külsőszférás elektronátadást -, addig a Ni(II)porfirinnél az elektronakceptor koncentrációjának növelésével egyre hosszabb lett a triplett gerjesztett állapot élettartama. Utóbbit a $\mathrm{MV}^{2+}$ természetesen kioltotta dinamikus kölcsönhatás révén, nagy időfelbontású mérésekkel is igazolva a redukcióját eredményező elektronátadás hatékonyságát.

\subsubsection{Oxidatív fotokatalitikus rendszerek}

Anionos és kationos szabadbázisú és Mn(III)-porfirinek mint fotokatalizátorok alkalmazásával különböző aromás szerkezetű szerves vegyületek oxigénezési reakcióit valósítottuk meg a Zágrábi Egyetem munkatársaival együttműködve ${ }^{14-19}$. E kísérletekben acetronitril és víz keveréke volt az oldószer, melyet levegővel ill. oxigénnel telítettünk, s a látható fényü besugárzás csak a porfirineket gerjesztette. A szabadbázisú porfirinek esetében csak az érzékenyítési reakció jöhetett számításba, vagyis a hosszú élettartamú, triplett gerjeszett állapotú porfirin az alapállapotú (triplett) oxigénmolekulával ütközve azt reakcióképesebb szingulett gerjesztett állapotba $\left({ }^{1} \mathrm{O}_{2}\right)$ hozza. A Mn(III)porfirinek erősebb oxidáló hatást tudtak kifejteni, mert a központi fémionhoz axiálisan kötődő hidroxo ligandum fotooxidációjával hidroxilgyököt generáltak (5). Az előző reakcióban képződő $\mathrm{Mn}$ (II)-porfirin termikusan oxidálódik (6), s az így keletkező Mn(IV)-oxo származék diszproporcionálódása ugyancsak nagyon reaktív $\mathrm{Mn}(\mathrm{V})$-oxo részecskét eredményez (7), ami telítetlen kötések epoxidálásában különösen hatékony.

$(\mathrm{P}) \mathrm{Mn}^{\mathrm{III}} \mathrm{OH}+\mathrm{h} v \rightarrow(\mathrm{P}) \mathrm{Mn}^{\mathrm{II}}+\cdot \mathrm{OH}$

$2(\mathrm{P}) \mathrm{Mn}^{\mathrm{II}}+\mathrm{O}_{2} \rightarrow 2(\mathrm{P}) \mathrm{Mn}^{\mathrm{IV}}=\mathrm{O}$

$2(\mathrm{P}) \mathrm{Mn}^{\mathrm{IV}}=\mathrm{O}+\mathrm{H}^{+} \leftrightarrows(\mathrm{P}) \mathrm{Mn}^{\mathrm{V}}=\mathrm{O}+(\mathrm{P}) \mathrm{Mn}^{\mathrm{III}} \mathrm{OH}$

Emellett a gerjeszett kiindulási Mn(III)-porfirin reakciója oldott oxigénnel töltésátvitel révén $\mathrm{Mn}(\mathrm{IV})$-porfirinszuperoxid komplex képződéséhez vezet (8), mely hidrogénelvonásra képes, így telített szénhidrogéneket különböző oxo-származékokká alakít.

$(\mathrm{P}) \mathrm{Mn}^{\mathrm{III}}+\mathrm{O}_{2}+\mathrm{h} v \rightarrow(\mathrm{P}) \mathrm{Mn}^{\mathrm{IV}}-\mathrm{O}_{2}{ }^{\cdot-}$

Ezen fotokatalitikus reakciók a kiindulási szerves molekulák szerkezetétől, összetételétől függően megfelelő reakciókörülmények mellett jó szelektivitással vezettek különböző funkcionalizált, potenciálisan bioaktív termékekhez. Pl. az analóg furán- és tiofén-származékok esetében utóbbi gyürün a reakcióképesség sokkal kisebb volt a megnövekedett aromaticitás miatt ${ }^{16,18}$. A heteroatom típusa mellett pozíciója és a fotokatalizátor töltése is jelentősen befolyásolta a végtermékeket.

\section{Szerves vegyületek fotolízise}

Szerves vegyületek fotokatalitikus oxigénezési reakcióihoz kapcsolódva különböző, telítetlen $\mathrm{C}=\mathrm{C}$ kettőskötést ill. aromás gyürüt tartalmazó molekulák közvetlen fotogerjesztésével kiváltott átalakulásait is vizsgáltuk horvát kollégáinkkal együttmüködve. E kísérletekhez szerves, alapvetőn apoláris oldószereket (mint pl. n-hexán) alkalmaztunk. Mivel a kiindulási vegyületek színtelenek voltak, ibolyántúli fénnyel sugároztuk be őket. Aromás gyűrühöz orto-helyzetben kapcsolódó vinil- és fenil-butadién esetében az alifás vázon lévő metilcsoport jelenléte (1-(3-metil-4-fenilbuta-1,3-dienil)-2-vinilbenzol) erőteljesen befolyásolta a végbemenő reakciót, s így a végterméket ${ }^{20}$. A metil-szubsztituens nélküli molekulák cikloaddíciós gyűrüzárási reakciót mutattak a párhuzamosan elhelyezkedő kettőskötések felnyílásával, ami naftalin- vagy dihidronaftalin-származékok képződéséhez vezetett, míg a dibutadién származékokból (1,2-bisz(4-fenilbuta-1,3-dienil)benzol) bi-és triciklusos vegyületek jöttek létre. A dibutadién-vegyületek dimetilezett származékai viszont csak geometriai $(Z-E)$ izomerizációt mutattak. Fontos megjegyezni, hogy a szubsztituálatlan (metilcsoport nélküli) butadién-származékok esetében is $Z-E$ izomeriáció a végtermék felé vezető elsődleges fotokémai lépés, különösen ha a kiindulási vegyület tartalmaz $Z$ geometriájú részt, ugyanis a további (gyürüzáródási) reakció megvalósulásához az $E, E$-izomerek biztosítják a kedvező szerkezetet ${ }^{20}$.

Amennyiben az előbbi vegyületek metilcsoport nélküli származékai a butadién-lánc(ok) végén lévő fenilcsoporton para-helyzetben fluoro, nitro vagy dimetilamino szubsztituenst tartalmaznak, UV-besugárzás hatására mutatott viselkedésük jelentősen eltér egymástól ${ }^{21}$. A mono- és difluoro származékok esetében továbbra is hatékony intramolekuláris cikloaddíció valósul meg. A mono-dimetilamino származék is mutatja ezt a reakciót, de jóval kisebb hatékonysággal, míg a bisz(dimetilamino) vegyület csak geometriai izomerizációra képes a szubsztituensek által előidézett sztérikus gátlás miatt. A mono- és dinitro származékok fotokémiailag inaktívnak bizonyultak.

\section{Heterogén fotokatalitikus rendszerek}

\section{1 $\mathrm{TiO}_{2}$-alapú katalizátorokkal}

A fotoaktív félvezetök közt a legszélesebb körben alkalmazott a titán-dioxid, mert kémiailag nagyon stabil, fotokatalitikus célokra megfelelő változatai viszonylag olcsón előállíthatók, s ezekkel közeli UV fény hatására hatékony töltésszeparáció valósítható meg. Előszeretettel használják szerves szennyezőanyagok, pl. igen kis koncentrációjú biológiailag aktív vegyületek (gyógyszerhatóanyagok, növényvédőszerek) lebontására vizes rendszerekben. Ilyenkor 
a besugárzás során képződő elektron-lyuk pár $\left(\mathrm{e}^{-}, \mathrm{h}^{+}\right)$alkotói (9), ha a rekombinációkat elkerülve elérik a katalizátor felszínét, levegővel vagy oxigénnel telített rendszerben erösen oxidáló ágenseket generálnak (10-12).

$\mathrm{TiO}_{2}+\mathrm{h} v \rightarrow \mathrm{TiO}_{2}\left(\mathrm{e}^{-}, \mathrm{h}^{+}\right)$

$\mathrm{TiO}_{2}\left(\mathrm{~h}^{+}\right)+\mathrm{H}_{2} \mathrm{O}_{\mathrm{ads}} \rightarrow \mathrm{TiO}_{2}+\mathrm{HO}^{\bullet}+\mathrm{H}^{+}$

$\mathrm{TiO}_{2}\left(\mathrm{e}^{-}\right)+\mathrm{O}_{2 \text { ads }} \rightarrow \mathrm{TiO}_{2}+\mathrm{O}_{2}^{\cdot}$

$\mathrm{TiO}_{2}\left(\mathrm{e}^{-}\right)+\mathrm{O}_{2}^{\cdot-} \rightarrow \mathrm{TiO}_{2}+\mathrm{O}_{2}^{2-}$

Oxigénmentesített rendszerben nem képződik szuperoxid gyökanion, ami, bár kisebb oxidációs potenciálú, mint a hidroxilgyök, bizonyos kötések felszakításában hatékonyabb. Így sikerült bebizonyítanunk, hogy oldott oxigén jelenléte nélkül az aromás gyürük nem hasíthatók fel, hiába valósul meg többszörös hidroxileződés az HO• hatására ${ }^{22}$. A nitrofurantoin (NFT) (5. ábra) elterjedt gyógyszerhatóanyag, mely ugyan fotokatalizátor nélkül is átalakul UV fény hatására, de $\mathrm{TiO}_{2}$ jelenlétében eröteljesen megnő a bomlási sebessége ugyanakkora fényintenzitás esetén ${ }^{23}$.

Az elsődleges fotokémai lépést, egy viszonylag gyors $E-Z$ izomerizációt követően, ill. azzal párhuzamosan (mindkét izomerből) játszódik le a NFT hidrolízise nitrofuraldehidre (NFA) és aminohidantoinra (AHD) (5. ábra).<smiles>N=C(N)C(=O)c1ccc([N+](=O)[O-])o1</smiles>

5. Ábra. Nitrofurantoin (NFT), nitrofuraldehid (NFA) és aminohidantoin (AHD) szerkezeti képlete

A $Z$ izomer sokkal reakcióképesebb; még fény nélkül is hidrolízist szenved. Katalizátor nékül a NFA fotolízise egy viszonylag stabil köztitermék, 5-hidroxifurán-2-karbaldehid felhalmozódásához vezet néhány származéka kíséretében, melyek azután nagyon lassan bomlanak. Ugyanakkor az NFA fotokatalízise során teljesen eltűnnek, miközben poláris alifás köztitermékek képződnek. Az NFA-tól eltérően az AHD közvetlen besugárzásra nem alakul át, de levegővel telített rendszerben a fotokatalízis során lebomlik.

Abban az esetben, ha levegő helyett ózont táplálunk a fotokatalitikus rendszer vizes fázisába, jelentősen megnő a mineralizáció (vagyis az egyszerü szervetlen vegyületekké bontás) hatékonysága ${ }^{24,25}$, mégpedig gyakran szinergikus módon, ahogy a benzolszulfonsav (BS) bontásakor is ${ }^{26}$.
Ilyenkor az együttes bontási hatás nagyobb, mint a két módszer külön-külön mért hatásának összege. Az ózonizálás gyorsító hatását jól tükrözi a 6 . ábra.
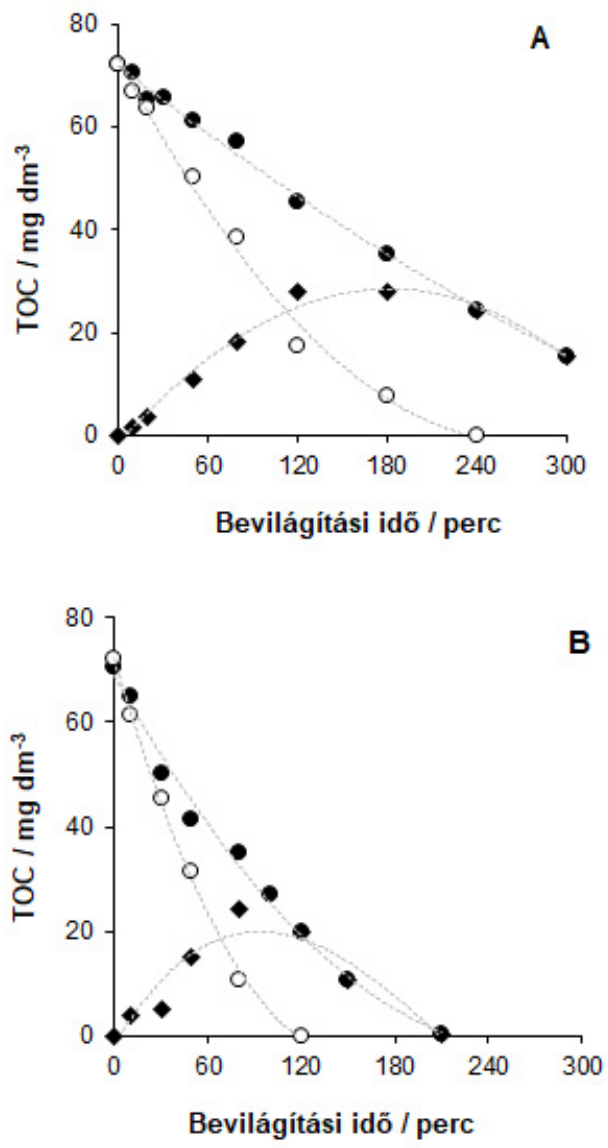

6. Ábra. A teljes szerves széntartalom (TOC) változása a besugárzási idő függvényében $1 \times 10^{-3} \mathrm{M}$ benzolszulfonsavat tartalmazó rendszerben (kezdeti pH=0) A) levegö, B) ózon jelenlétében végzett $\mathrm{TiO}_{2}$ alapú fotokatalízis során ( $1 \mathrm{~g} \mathrm{dm}^{-3} \mathrm{TiO}_{2}, \mathrm{UV}$ besugárázás), a teljes rendszerre $(\bullet)$, a kiindulási anyagra $(\mathrm{O})$ és képződő köztitermékekre $(\diamond)$ vonatkozóan

A szinergikus hatás az ózon és a gerjesztés révén a vezetési sávba került elektron közt lejátszódó reakcióval értelmezhető, mely végül hidroxilgyököt eredményez.

A fotokatalitikus hatékonyság növelésének egy további módja fémleválasztás a katalizátor felületére. A fém- (pl. Ag) klaszterek elektroncsapdaként müködve akadályozzák az elektron-lyuk rekombinációt és elősegítik a redukáló reakciókat. Ezt sikerült demonstrálnuk a BS fö bomlási köztiterméke, a 4-hidoxibenzolszulfonsav mineralizálásával ózonizálással kombinált $\mathrm{Ag}-\mathrm{TiO}_{2}$ alapú fotokatalízissel ${ }^{27}$.

További lehetőség a hatékonyságnövelésre, ha a fotokatalizátor a látható fénnyel is gerjeszthető. Ezt a megfelelö elem, pl. nitrogén adagolásával lehet elérni, mely csökkenti a tiltott sáv szélességét, de ezzel az oxidáló erősséget is. Ezért érdemes ezüstözéssel továbbra is fokozni a redukciós hatást, ahogy a 7 . ábra szemlélteti ${ }^{28}$. 


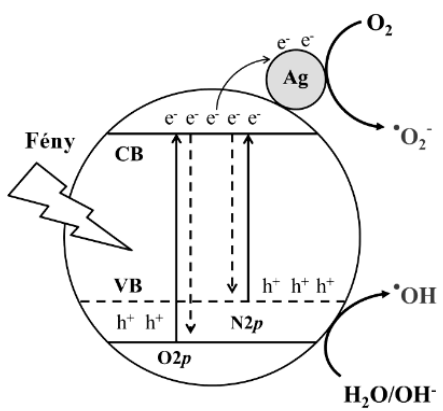

7. Ábra. Szerves szennyezők oxidatív lebontásához alkalmazott, nitrogénnel adalékolt és ezüstözött titán-dioxid fotokatalizátor müködése levegővel telített vizes rendszerben

Az oxidatív bontásokhoz alkalmazott fotokatalizátorok hatékonyságának meghatározásához olyan módszereket fejlesztettünk ki - részben már korábban is alkalmazott vegyületekkel -, melyek révén viszonylag egyszerüen és megbízhatóan mérhető a különböző fotogenerált oxidáló ágensek koncentrációja ${ }^{29,30}$.

\subsection{Ferritalapú katalizátorokkal}

A titán-dioxid mellett egyre nagyobb teret hódítanak a stabil színes heterogén fotokatalizátorok. Ilyenek a különböző fém-oxidokkal kombinált ferritek is, melyek mint heterogén foto-Fenton katalizátorok ismertek. Vizsgálataink vas(II)-vel módosított réz(II)-ferritekre irányultak, s megállapítottuk, hogy a különböző összetételü $\mathrm{Cu}_{(\mathrm{x})}^{\mathrm{II}} \mathrm{Fe}_{(1-\mathrm{x})}^{\mathrm{II}}$ $\mathrm{Fe}_{2}{ }_{2} \mathrm{O}_{4}$ nanorészecskék közül szerves festékek bontásában az bizonyult a leghatékonyabbnak, melyre $\mathrm{x}=0,4$ volt $^{31}$. Ez valószínűleg annak a következménye, hogy ez az öszszetétel speciális kristályszerkezetü; a gömb- és a tüszerü közötti átmenetet mutató kristályokból áll, míg a többiek tisztán az egyik vagy másik alakzatot képviselik. Ennél a nanorészecskénél 2,0 eV a gerjesztési küszöbenergia, így a látható fényt szélesebb tartományban hasznosítja. Több felhasználási ciklus után is stabilnak bizonyult a hatékonysága. A heterogén foto-Fenton rendszerekben, melyek $\mathrm{H}_{2} \mathrm{O}_{2}$ - $\mathrm{t}$ is tartalmaznak, a következö reakciók generálnak oxidatív ágenseket, föként hidroxilgyököt (13-15):

$$
\begin{aligned}
& \mathrm{Fe}(\mathrm{II})+\mathrm{H}_{2} \mathrm{O}_{2} \rightarrow \mathrm{Fe}(\mathrm{III})+\mathrm{HO}^{\bullet}+\mathrm{HO}^{-} \\
& \mathrm{Fe}(\mathrm{III})+\mathrm{H}_{2} \mathrm{O}_{2} \rightarrow \mathrm{Fe}(\mathrm{II})+\mathrm{HOO}^{\bullet}+\mathrm{H}^{+} \\
& \mathrm{H}_{2} \mathrm{O}_{2}+\mathrm{e}^{-} \rightarrow \mathrm{HO}^{\bullet}+\mathrm{HO}^{-}
\end{aligned}
$$

Továbbá ebben az esetben is a vezetési sáv elektronja hidroxilgyököt képez a vízzel vagy hidroxidionnal reagálva.

\subsection{CdS/ZnS alapú katalizátorokkal}

Az oxidációs típusú heterogén fotokatalizátorok mellett redukciós rendszerekkel is foglalkoztunk, vagyis amelyeknek a fő terméke elektrontároló üzemanyag. Ilyeneket elsősorban a napsugárzás látható tartományának hasznosítására fejlesztenek ki, ahogy az esetünkben is történt. CdS/ZnS kompozit alkalmazásával sikerült olyan vizes rendszerből hidrogént fejleszteni, melyben szulfidionok biztosították a redukcióhoz szükséges elektronokat (8. ábra) ${ }^{32}$. Mivel a szulfid a kőolajfeldolgozás során nagy mennyiségben képződő melléktermék, hasznosításával - megújuló napenergia segítségével - környezetbarát üzemanyag állítható elő.

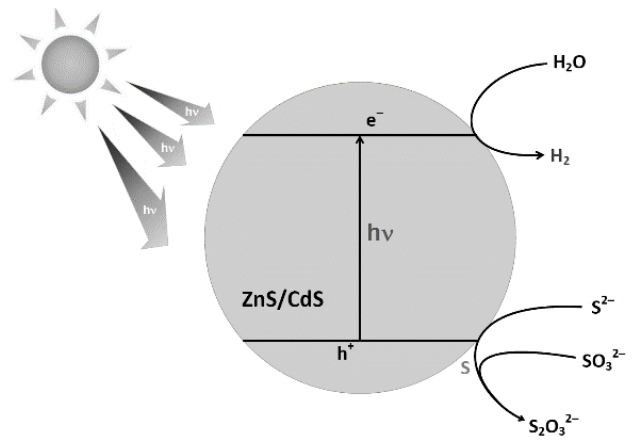

8. Ábra. Egyszerüsített séma napsugárzással működtetett, $\mathrm{CdS} / \mathrm{ZnS}$ fotokatalizátoron alapuló hidrogénfejlesztésre hulladék szulfid mint elektrondonor alkalmazásával

\section{Köszönetnyilvánítás}

A szerzők köszönetüket fejezik ki a Nemzeti Kutatási, Fejlesztési és Innovációs Hivatalnak a Magyar-Francia TÉT Együttműködési Program keretében a 2019-2.1.11TÉT-2019-00033 projekt, valamint a 2020-4.1.1-TKP2020 Tematikus Kiválósági Program keretében a TKP2020IKA-07 projekt által nyújtott támogatásért.

\section{Hivatkozások}

1. Valicsek, Z.; Horváth, O. Microchem. J. 2013, 107, 47-62. https://doi.org/10.1016/j.microc.2012.07.002

2. Valicsek, Z.; Kiss, M. P.; Fodor, M. A.; Imran, M.; Horváth, O. Hungarian J. Ind. Chem. 2017, 45, 29-36. https://doi.org/10.1515/hjic-2017-0006

3. Harrach, G.; Valicsek, Z.; Horváth, O. Inorg. Chem. Commun. 2011, 14, 1756-1761.

https://doi.org/10.1016/j.inoche.2011.08.003

4. Valicsek, Z.; Horváth, O.; Patonay, K. J. Photochem. Photobiol. A Chem. 2011, 226, 23-35. https://doi.org/10.1016/j.jphotochem.2011.10.011

5. Valicsek, Z.; Eller, G.; Horváth, O. Dalt. Trans. 2012, 41, 13120-13131. https://doi.org/10.1039/c2dt31189e

6. Horváth, O.; Valicsek, Z.; Harrach, G.; Lendvay, G.; Fodor, M. A. Coord. Chem. Rev. 2012, 256, 1531-1545. https://doi.org/10.1016/j.ccr.2012.02.011

7. Valicsek, Z.; Horváth, O.; Lendvay, G.; Kikaš, I.; Škorić, I. J. Photochem. Photobiol. A Chem. 2011, 218, 143-155. https://doi.org/10.1016/j.jphotochem.2010.12.014

8. Horváth, O.; Valicsek, Z.; Fodor, M. A.; Major, M. M.; Imran, M.; Grampp, G.; Wankmüller, A. Coord. Chem. Rev. 2016, 325, 59-66. https://doi.org/10.1016/j.ccr.2015.12.011

9. Imran, M.; Kiss, M. P.; Valicsek, Z.; Horváth, O. Molecules 2019, 24, 1309-1322. https://doi.org/10.3390/molecules24071309

10. Imran, M.; Szentgyörgyi, C.; Eller, G.; Valicsek, Z.; Horváth, O. Inorg. Chem. Commun. 2015, 52, 60-63. https://doi.org/10.1016/j.inoche.2014.12.016 
11. Fodor, M. A.; Horváth, O.; Fodor, L.; Grampp, G.; Wankmüller, A. Inorg. Chem. Commun. 2014, 50, 110-112. https://doi.org/10.1016/j.inoche.2014.10.029

12. Fodor, M. A.; Horváth, O.; Fodor, L.; Vazdar, K.; Grampp, G.; Wankmüller, A. J. Photochem. Photobiol. A Chem. 2016, $328,233-239$. https://doi.org/10.1016/j.jphotochem.2016.06.011

13. Major, M. M.; Horváth, O.; Fodor, M. A.; Fodor, L.; Valicsek, Z.; Grampp, G.; Wankmüller, A. Inorg. Chem. Commun. 2016, 73, 1-3. https://doi.org/10.1016/j.inoche.2016.09.001

14. Kikaš, I.; Horváth, O.; Škorić, I. Tetrahedron Lett. 2011, 52, 6255-6259.

https://doi.org/10.1016/j.tetlet.2011.09.076

15. Kikaš, I.; Horváth, O.; Škorić, I. J. Mol. Struct. 2013, 1034, 62-68. https://doi.org/10.1016/j.molstruc.2012.09.005

16. Vuk, D.; Kikaš, I.; Molčanov, K.; Horváth, O.; Škorić, I. J. Mol. Struct. 2014, 1063, 83-91. https://doi.org/10.1016/j.molstruc.2014.01.055

17. Vuk, D.; Horváth, O.; Marinić, Ž.; Škorić, I. J. Mol. Struct. 2016, 1107, 70-76. https://doi.org/10.1016/j.molstruc.2015.11.036

18. Vuk, D.; Horváth, O.; Škorić, I. Catalysts 2019, 9, 304-315. https://doi.org/10.3390/catal9040304

19. Mlakić, M.; Šalić, A.; Bačić, M.; Zelić, B.; Šagud, I.; Horváth, O.; Škorić, I. Catalysts 2021, 11, 395-410. https://doi.org/10.3390/catal11030395

20. Škorić, I.; Kikaš, I.; Kovács, M.; Fodor, L.; Marinić, Z.; Molčanov, K.; Kojić-Prodić, B.; Horváth, O. J. Org. Chem. 2011, 76, 8641-8657. https://doi.org/10.1021/jo200691x

21. Grgičević, A.; Fodor, L.; Barić, D.; Poje, M.; Marinić, Ž.; Horváth, O.; Škorić, I. J. Photochem. Photobiol. A Chem. 2020, 400, 112690-112708. https://doi.org/10.1016/j.jphotochem.2020.112690

22. Szabó-Bárdos, E.; Markovics, O.; Horváth, O.; Törö, N.; Kiss, G. Water Res. 2011, 45, 1617-1628.

https://doi.org/10.1016/j.watres.2010.11.045
23. Szabó-Bárdos, E.; Cafuta, A.; Hegedüs, P.; Fónagy, O.; Kiss, G.; Babić, S.; Škorić, I.; Horváth, O. J. Photochem. Photobiol. A Chem. 2020, 386, 112093-112102. https://doi.org/10.1016/j.jphotochem.2019.112093

24. Horváth, O.; Szabó-Bárdos, E.; Zsilák, Z.; Bajnóczi, G. Period. Polytech. Chem. Eng. 2012, 56, 49-54. https://doi.org/10.3311/pp.ch.2012-2.01

25. Zsilák, Z.; Fónagy, O.; Szabó-Bárdos, E.; Horváth, O.; Horváth, K.; Hajós, P. Environ. Sci. Pollut. Res. 2014, 21, $11126-11134$ https://doi.org/10.1007/s11356-014-2527-2

26. Zsilák, Z.; Szabó-Bárdos, E.; Fónagy, O.; Horváth, O.; Horváth, K.; Hajós, P. Catal. Today 2014, 230, 55-60. https://doi.org/10.1016/j.cattod.2013.10.039

27. Fónagy, O.; Szabó-Bárdos, E.; Horváth, O.; Kiss, G. J. Photochem. Photobiol. A Chem. 2018, 366, 152-161. https://doi.org/10.1016/j.jphotochem.2018.04.054

28. Wafi, A.; Szabó-Bárdos, E.; Horváth, O.; Pósfai, M.; Makó, É.; Juzsakova, T.; Fónagy, O. Nanomaterials 2020, 10, 2261-2278. https://doi.org/10.3390/nano10112261

29. Wafi, A.; Szabó-Bárdos, E.; Horváth, O.; Makó, É.; Jakab, M.; Zsirka, B. J. Photochem. Photobiol. A Chem. 2021, 404, $112913-112923$ https://doi.org/10.1016/j.jphotochem.2020.112913

30. Fónagy, O.; Szabó-Bárdos, E.; Horváth, O. J. Photochem. Photobiol. A Chem. 2021, 407, 113057-113070. https://doi.org/10.1016/j.jphotochem.2020.113057

31. Khan, A.; Valicsek, Z.; Horváth, O. Nanomaterials 2020, 10, 921-937. https://doi.org/10.3390/nano10050921

32. Fodor, L.; Solymosi, B.; Horváth, O. J. Nanosci. Nanotechnol. 2019, 19, 509-515. https://doi.org/10.1166/jnn.2019.15794 


\section{Photoinduced processes in homogeneous and heterogeneous systems: spectroscopy, photolysis, and photocatalysis}

This brief summary has been devoted to introduce the most characteristic results of the Environmental and Inorganic Photochemistry Group of the University of Pannonia, achieved in the past decade. Their current research fields are partly connected to their earlier experiences with coordination compounds, partly belong to new routes with heterogeneous photocatalysts. In photolysis, the photoactive species are directly excited by UV or visible light, increasing their oxidation potential and reduction ability as well. It is true for both molecules in homogeneous systems and solid-state semiconductor particles as heterogeneous photocatalysts. In photocatalysis, the excited-state photoactive catalysts generally promote charge transfer between electron donor and acceptor species which would not react with each other in the ground state. In some cases, the catalysts just sensitize the reaction of a substrate which cannot be directly excited as a non-absorbing species. Here, the energy transfer takes place via collision.

In homogeneous systems, mostly water-soluble metalloporphyrins were studied. The free bases are planar tetradentate ligands as Fig. 1 shows. The anionic or cationic substituents ensure their solubility in water. From a structural point of view, metalloporphyrins belong to two main categories. If the metal center is small enough (its radius does not exceed $85-90 \mathrm{pm}$ ), it is located inside the coordination cavity of the ligand, in its plane. These in-plane (or regular) complexes are kinetically inert. If the size of the metal center is bigger, it cannot fit in the cavity, it is located out of the ligand plane. These out-of-plane complexes can only exist in equilibrium, mostly at the excess of the metal ions. This structural difference is manifested in their absorption spectra (Fig. 2); bands of the in-plane metalloporphyrins are blue-shifted compared to the bands of the corresponding free base, while those of the outof-plane complexes are red-shifted due to distortion of the ligand plane. The emission bands in both categories are blue-shifted because, due to the splitting of the $\mathrm{S}_{1}$ state for asymmetry reason, the free base emits from the lower $\left(\mathrm{S}_{1 \mathrm{x}}\right)$ state. Even the free base itself can be distorted if it is overcrowded by substituents as in the case of the octabromo derivative displaying a very strong red-shift (Fig. 2). Out-of-plane monoporphyrins can be associated at higher concentrations of the ligand and the metal ion, forming bis- or oligoporphyrins as the tail-tail connection of anionic lanthanide(III) monoporphyrins through a $\mathrm{Ln}^{3+}$ ion demonstrates (Fig. 3). The similar emission properties of these mono- and bisporphyrins confirm this structure with such a weak connection.

The photochemical behavior of the metalloporphyrins is strongly related to their structure. Upon excitation, the out-of-plane complexes undergo an irreversible ligand-to-metal charge transfer (LMCT), increasing the size of the metal center and promoting its dissociation. After demetallation, the oxidized porphyrin ring is irreversibly cleaved, unless an appropriate electron donor is in the system. Hence, the out-of-plane metalloporphyrins, taking also the equilibrium system into consideration, are not ideal candidates for photocatalysis. The in-plane complexes are just the opposite. If they are on their own, they do not display any photochemical reaction upon excitation. However, they can catalyze charge transfer in the presence of suitable electron donors and acceptors, generally through the metal center via outer-sphere mechanism. Photocatalytic systems based on cationic cobalt(III) and manganese(III) porphyrins proved to be characteristic examples of this behavior (see Fig. 4 and Eqs. 1, 2). Triethanolamine (TEOA) serves as a sacrificial electron donor, while methyl viologen $\left(\mathrm{MV}^{2+}\right)$ can be an efficient electron acceptor. In the first step, the excited metalloporphyrin oxidizes TEOA, reducing the metal center. The reduced metal center, also upon excitation, forwards the electron gained to the $\mathrm{MV}^{2+}$, producing $\mathrm{MV}^{*-}$ radical cation.
This species is very reductive, in the presence of a co-catalyst it can generate hydrogen from water, being capable of harnessing solar radiation.

Interestingly, the analogous nickel(II) porphyrin, under the same conditions, displayed an other mechanism for the production of $\mathrm{MV}^{*}$. In this case, no reduced metal center could be observed. Instead, the electron donor (TEOA) was connected to the complex in the ground state (Eq. 3). The excitation of this associate resulted in a direct electron transfer from the electron donor to the methyl viologen (Eq. 4). This mechanism has been confirmed by flash photolysis experiments.

In-plane manganese(III) porphyrins, both anionic and cationic, as well as their free bases, could be utilized for various oxygenation reactions of different organic compounds containing aryl moieties. The free bases could only generate singlet oxygen $\left({ }^{1} \mathrm{O}_{2}\right)$ via sensitization, while the complexes can produce both hydroxyl radicals and very reactive $\mathrm{Mn}(\mathrm{V})$-oxo species, along with a Mn(IV) superoxide complex (Eqs. 5-8). These very oxidative agents produce various final products of potential bioactivity in rather selective reactions, depending on the starting substrate, the type and charge of the catalyst as well as the oxygen concentration. For example, the thiophene compounds were much less reactive than the analogous furyl derivatives, due to their very deviating aromaticies. The position of the heteroatom also affected the reaction mechanisms.

Photolyses of several organic compounds with $\mathrm{C}=\mathrm{C}$ double bonds were carried out, too. In the case of parallel double bonds, cycloaddition reactions took place, leading to ring closure. In the case of dibutadiene derivatives, even tricyclic compounds were formed. However, the presence of a methyl substituent at the double bond could hinder this reaction, and mostly $Z-E$ isomerization occurred if any. Without the methyl group, a fluoro, nitro, or dimethylamino substituent in para position on the benzene ring at the end of the butadiene chain dramatically affected the course of the photolysis. The fluoro derivatives underwent efficient cyclizations, the reactivities of the dimethylamino species were much lower, while the nitro derivatives proved to be photochemically inactive.

In heterogeneous photocatalytic systems, $\mathrm{TiO}_{2}$ was mostly applied, due to its stability, low cost, and high efficiency upon UV excitation. In aerated systems, it can be utilized for oxidative degradation of various organic pollutants, due to the generation of highly oxidative agents (see Eqs. 9-12). Photolytic and photocatalytic decomposition of a pharmaceutical, nitrofurantoin (NFT), and their hydrolytic products (NFA and AHD) (Fig. 5) were examined. While only partly conversions were observed during the photolyses, almost total mineralizations were achieved by photocatalyses. The efficiency of oxidative photocatalytic decomposition was enhanced, even synergically, by combination with ozonation, e.g., for mineralization of benzenesulfonic acid (Fig. 6). Besides, silverization of the catalyst surface also increased the degradation rate. Visible light could be utilized for this purpose with nitrogen-doped $\mathrm{TiO}_{2}$ (Fig. 7). Also visible-light-driven oxidative degradations of various dyes were realized with heterogeneous photo-Fenton type systems based on iron(II) doped copper ferrite nanoparticles $\left(\mathrm{Cu}^{\mathrm{II}}{ }_{(\mathrm{x})} \mathrm{Fe}^{\mathrm{II}}{ }_{(1-x)} \mathrm{Fe}^{\mathrm{III}}{ }_{2} \mathrm{O}_{4}\right)$, where the one with $\mathrm{x}=0.4$ proved to be the most efficient, due to its special morphology. Eqs. 13-15 show the formation of the oxidative agents in this system. CdS/ZnS catalysts were utilized for reductive photocatalysis to produce $\mathrm{H}_{2}$ (as eco-friendly fuel) from water in the presence of $\mathrm{S}^{2-}$ ions as electron donors available as industrial side-product. This system is suitable for solar energy storage (Fig. 8). 